\title{
AVAILABILITY AND STORAGE OF HAZARDOUS PRODUCTS IN HOUSEHOLDS IN THE METROPOLITAN REGION OF MANAUS: A POPULATION-BASED SURVEY, 2015
} Disponibilidade e armazenamento de produtos perigosos em domicílios
da Região Metropolitana de Manaus: estudo de base populacional, 2015

\author{
Gustavo Magno Baldin Tigumana,* (1), Marina Borges Dias de Almeida ${ }^{a}$ (1), \\ Marcus Tolentino Silva ${ }^{b}$ (D), Tais Freire Galvao ${ }^{a}$ (D)
}

\section{ABSTRACT}

Objective: The availability of hazardous products in households increases the risks of poisoning. The present study aimed to assess the frequency and associated factors of the availability and storage of hazardous products in residences in the metropolitan region of Manaus.

Methods: Population-based and cross-sectional study conducted in 2015 with adults selected with three-stage probabilistic sampling. Participants were interviewed face-to-face. Prevalence ratio (PR) of the presence of hazardous products (presence of chumbinho [illegal anti-cholinesterase rodenticide], artisanal cleaning products, and unsafe storage of these products and medications) and $95 \%$ confidence intervals $(95 \% \mathrm{Cl})$ were calculated with Poisson regression with robust variance, weighted by the complex sampling method adopted.

Results: A total of 4,001 participants was included, of which $53.0 \%(95 \% \mathrm{Cl} 51.5-54.6)$ reported presence of hazardous products in their households, 36.3\% (95\%Cl 34.8-37.8) had unsafe storage, $16.2 \%(95 \% \mathrm{Cl} 15.1-17.4)$ had artisanal cleaning products, and $8.2 \%(95 \% \mathrm{Cl} 7.4-9.1)$ had chumbinho. Households with children $\leq 5$ years old had safer storage ( $P R=0.78 ; 95 \% \mathrm{Cl} 0.71-0.86)$ and more artisanal products $(P R=1.30 ; 95 \% \mathrm{Cl} 1.11-1.51)$. Presence of artisanal products was higher in lower educational levels (PR $=2.20 ; 95 \% \mathrm{Cl}$ 1.36-3.57) and lower economic classifications ( $P R=1.63$; $95 \%$ Cl 1.25-2.13).

\section{RESUMO}

Objetivo: A disponibilidade de produtos perigosos em domicílios aumenta os riscos de intoxicações. Este estudo objetivou avaliar a frequência e os fatores associados à disponibilidade e armazenamento de produtos perigosos em residências da Região Metropolitana de Manaus.

Métodos: Estudo transversal de base populacional realizado em 2015 com adultos selecionados por amostragem probabilística em três estágios. Os participantes foram entrevistados pessoalmente. A razão de prevalência (RP) da presença de produtos perigosos (presença de chumbinho [rodenticida anticolinesterase ilegal], produtos de limpeza artesanais e armazenamento inseguro desses produtos e de medicamentos) e intervalos de confiança de 95\% (IC95\%) foram calculados por regressão de Poisson com variância robusta, ponderada pela amostragem complexa adotada. Resultados: 4.001 participantes foram incluídos, dos quais 53,0\% (IC95\% 51,5-54,6) reportaram a presença de produtos perigosos em seus domicílios, 36,3\% (IC95\% 34,8-37,8) apresentaram armazenamento inseguro, 16,2\% (IC95\% 15,1-17,4) possuíam produtos de limpeza artesanais e 8,2\% (IC95\% 7,4-9,1) possuíam chumbinho. Os domicílios com crianças menores de 5 anos apresentaram armazenamento mais seguro (RP=0,78; IC95\% $0,71-0,86)$ e mais produtos artesanais ( $R P=1,30$; IC95\% $1,11-$ 1,51). Presença de produtos artesanais foi maior em menores níveis de escolaridade (RP=2,20; IC95\% 1,36-3,57) e menores classificações econômicas (RP=1,63; IC95\% 1,25-2,13).

*Corresponding author. E-mail: gustavo.tiguman@gmail.com (G.M.B.Tiguman).

aniversidade Estadual de Campinas, Campinas, SP, Brazil.

bUniversidade de Sorocaba, Sorocaba, SP, Brazil.

Received on May 06, 2020; approved on August 09, 2020; available online on February 03, 2021. 
Conclusions: Over half of the households in the metropolitan region of Manaus kept hazardous products; one-third stored them unsafely. Artisanal cleaning products and chumbinhowere frequently present. Households with children had safer storage of products, and socioeconomic factors affected the availability of such hazardous products.

Keywords: Poisoning; Hazardous substances; Sanitizing products; Sanitizing product storage; Household products; Health surveys.
Conclusões: Mais da metade dos domicílios da Região Metropolitana de Manaus possuía produtos perigosos; um terço os armazenava sem segurança. Produtos de limpeza artesanais e chumbinho estavam frequentemente presentes. Os domicílios com crianças apresentaram armazenamento mais seguro de produtos e fatores socioeconômicos afetaram a disponibilidade de tais produtos perigosos.

Palavras-chave: Envenenamento; Substâncias perigosas; Saneantes; Armazenamento de saneantes; Produtos domésticos; Inquéritos epidemiológicos.

\section{INTRODUCTION}

Child poisoning mostly occurs at home with products easily accessible to children. ${ }^{1}$ Unintentional injuries, especially those related to poisoning, are an important cause of morbidity and mortality in children and adolescents worldwide. ${ }^{2-4}$ Roughly one million unintentional exposures in children $\leq 5$ years old were reported in the United States in 2018.5 Children in this age group are highly vulnerable to unintentional injuries as a result of their natural curiosity to explore their surroundings, their small stature, and their lack of perception of danger. ${ }^{6}$

Exposure to household cleaning products were the second most common poisoning exposures in children aged 5 or less, accounting for $11 \%$ of the reported cases in the US in $2018 .^{5}$ These cleaning substances accounted for $10 \%$ of all poisoning calls in Australia in 2015; one-third of these cases were related to children $\leq 5$ years old. ${ }^{7}$ Two thirds of child poisonings managed in a Romanian hospital between 2014 and 2016 were nonmedication related, and household chemicals were the most frequent agents. ${ }^{8}$ In Malaysia, from 2006 to 2015 , over $90 \%$ of the poisonings occurred at home through ingestion, and approximately half of the unintentional cases occurred in children. ${ }^{9}$ In 2013, 73\% of the patients treated for poisonings in a Brazilian Poison Control Center were children aged $\leq 5$; cleaning products were the second most frequent cause of poisonings, which mostly occurred at home. ${ }^{10}$

Childhood poisonings show higher lethality in low- and middle-income countries, because they are associated with poverty and weaker market regulations. ${ }^{11}$ Illegal products, with hazardous substances in their formulations, also play a role in poisoning exposures among children, leading to systemic symptoms and high number of hospital admissions. ${ }^{12}$

Brazil lacks epidemiological data about the availability and storage of such substances, especially in underdeveloped regions. We aimed to assess the frequency of the availability and unsafe storage of hazardous products and associated factors in households in the Brazilian Amazon.

\section{METHOD}

This was a cross-sectional and population-based study, conducted between May and August 2015, which interviewed adults living in the metropolitan region of Manaus. The present analysis is part of a survey designed to assess the offer and usage of healthcare services in the region. ${ }^{13}$

We selected adults $\geq 18$ years old with probabilistic sampling in three stages, by clusters, and stratified by sex and age quotas. Sample size was calculated in 4,000 interviewees, considering the estimated adult population in this region and a conservative prevalence of healthcare services utilization. ${ }^{13}$

Trained interviewers with previous experience in quantitative surveys collected data at the participants' residences using questionnaires on electronic devices after obtaining written informed consent from each participant.

The dependent variable selected for this study was the availability of hazardous products in the households with $95 \%$ confidence intervals $(95 \% \mathrm{CI})$, which was assessed with the self-reported presence of chumbinho (an illegal anti-cholinesterase rodenticide) or artisanal household cleaning products (products not commercially registered by the health authority), or the unsafe storage of household cleaning products, pesticides, and medications. The presence of each isolated outcome was also investigated (presence of chumbinho, artisanal household cleaning products, unsafe storage).

Data were obtained from the following question: "For each product listed below (household cleaning products: bleach, fabric softener, disinfectant, detergents, soap, caustic soda; chumbinho for rats; insecticides; and medications), are they stored in your household?" (yes or no). In case of positive answer, the following questions were asked regarding each product: "Is it artisanal?" (yes or no) - to determine whether the product was considered illegal - and "Is it stored in a high place or locked up?" (yes or no) — to determine unsafe storage. 
Independent variables included the municipality (capital [Manaus] or interior towns); number of dwellers in each household $(1-2,3-5, \geq 6)$; presence of children $\leq 5$ years old living in the household (yes or no); interviewee's educational level (higher education degree or above, complete high school, complete elementary school, less than elementary school); economic classification $(\mathrm{A} / \mathrm{B}, \mathrm{C}, \mathrm{D} / \mathrm{E}$, according to the Brazilian Economic Classification Criteria, 14 in which A refers to the wealthiest, and E, to the poorest); and visit from the Family Health Program (a Brazilian primary care program of the Unified Health System [Sistema Único de Saúde, SUS] based on care for the whole family that includes household visits) over the last 12 months (yes or no).

The list of products was asked randomly in each interview to avoid bias of desensitization of the interviewees when there was similarity between the response options, especially in the latter questions. ${ }^{15}$

The data were analyzed descriptively and adjusted for covariates using Poisson regression with robust variance. All variables were included in the adjusted multivariate analysis as covariates. We calculated prevalence ratio (PR) and 95\% confidence intervals $(95 \% \mathrm{CI})$ for the presence of hazardous products for each independent variable. Statistical significance was considered for $\mathrm{p}<0.05$. We calculated deviance statistic and the Pearson's Goodness-of-Fit test to assess the appropriateness of Poisson regression models. ${ }^{16}$ All analyses were performed in Stata 14.2 (StataCorp, College Station, TX) and considered the complex sample design (svy command) to properly weight the sample.

The Research Ethics Committee of Universidade Federal do Amazonas approved the project, under Report No. 974.428 dated March $3^{\text {rd }}, 2015$ (Certificate of Presentation for Ethical Appreciation [Certificado de Apresentação para Apreciação Ética] at Brazil Platform: 42203615.4.0000.5020). All participants signed an informed consent form.

\section{RESULTS}

We included 4,001 participants, of which $87.0 \%$ lived in Manaus City (Table 1). Most households had 3-5 dwellers in the same residence, no children $\leq 5$ years old, and had not received a visit from the Family Health Program over the last 12 months before interview. Most interviewees had an educational

Table 1 Characteristics of participants and presence of hazardous products, unsafe storage, artisanal products, and chumbinho in households (Metropolitan Region of Manaus, 2015; $n=4,001$ ).

\begin{tabular}{|c|c|c|c|c|c|c|c|c|c|c|}
\hline & \multirow{2}{*}{\multicolumn{2}{|c|}{$\begin{array}{l}\text { Population } \\
\text { frequency }\end{array}$}} & \multicolumn{8}{|c|}{ Presence in the household } \\
\hline & & & \multicolumn{2}{|c|}{ Hazardous } & \multicolumn{2}{|c|}{ Unsafe storage } & \multicolumn{2}{|c|}{ Artisanal } & \multicolumn{2}{|c|}{ Chumbinho } \\
\hline & $\mathbf{n}$ & $\%$ & $\mathbf{n}$ & $\%$ & $\mathrm{n}$ & $\%$ & $\mathbf{n}$ & $\%$ & $n$ & $\%$ \\
\hline \multicolumn{11}{|l|}{ Municipality } \\
\hline Manaus & 3,479 & 87.0 & 1,869 & 55.1 & 1,280 & 36.8 & 577 & 16.6 & 295 & 8.5 \\
\hline Interior towns & 522 & 13.1 & 195 & 39.6 & 135 & 25.9 & 57 & 10.9 & 34 & 6.5 \\
\hline \multicolumn{11}{|l|}{ Number of dwellers } \\
\hline $1-2$ & 854 & 21.3 & 384 & 45.9 & 290 & 34.0 & 101 & 11.8 & 45 & 5.3 \\
\hline $3-5$ & 2,274 & 56.8 & 1,255 & 56.7 & 868 & 38.2 & 379 & 16.7 & 215 & 9.5 \\
\hline$\geq 6$ & 873 & 21.8 & 425 & 50.9 & 257 & 29.4 & 154 & 17.6 & 69 & 7.9 \\
\hline \multicolumn{11}{|l|}{ Children $\leq 5$ years old } \\
\hline No & 2,418 & 60.4 & 1,267 & 53.9 & 937 & 38.8 & 339 & 14.0 & 200 & 8.3 \\
\hline Yes & 1,098 & 39.6 & 797 & 52.0 & 478 & 30.2 & 295 & 18.6 & 129 & 8.2 \\
\hline \multicolumn{11}{|l|}{ Educational level } \\
\hline Higher education or above & 158 & 4.0 & 82 & 52.6 & 60 & 37.7 & 17 & 10.8 & 13 & 8.2 \\
\hline High school & 1,903 & 47.6 & 966 & 52.1 & 705 & 37.1 & 238 & 12.5 & 176 & 9.3 \\
\hline Elementary school & 1,185 & 29.6 & 576 & 50.6 & 413 & 34.9 & 157 & 13.2 & 80 & 6.8 \\
\hline Less than elementary school & 755 & 18.9 & 440 & 59.8 & 237 & 31.4 & 223 & 29.5 & 60 & 8.0 \\
\hline \multicolumn{11}{|l|}{ Economic classification } \\
\hline$A / B$ & 629 & 15.7 & 342 & 56.1 & 264 & 42.0 & 67 & 10.7 & 76 & 12.1 \\
\hline C & 2,285 & 57.1 & 1,161 & 52.6 & 827 & 36.2 & 324 & 14.2 & 186 & 8.1 \\
\hline $\mathrm{D} / \mathrm{E}$ & 1,087 & 27.2 & 561 & 52.6 & 324 & 29.8 & 243 & 22.4 & 67 & 6.2 \\
\hline \multicolumn{11}{|c|}{ Visit by Family Health Program agents* } \\
\hline Yes & 1,277 & 31.9 & 696 & 57.5 & 219 & 17.2 & 481 & 37.7 & 105 & 8.2 \\
\hline No & 2,724 & 68.1 & 1,368 & 51.2 & 415 & 15.2 & 934 & 34.3 & 224 & 8.2 \\
\hline
\end{tabular}

*In the previous 12 months. 
level up to high school and belonged to the middle class (economic classification $\mathrm{C}$ ).

Availability of hazardous products was self-reported in 53.0\% (95\%CI 51.5-54.6) of households, whereas unsafe storage was present in 36.3\% (95\%CI 34.8-37.8), artisanal cleaning products in $16.2 \%$ (95\%CI 15.1-17.4), and chumbinho in $8.2 \%$ (95\%CI 7.4-9.1).
In the multivariate analysis (Tables 2 and 3), living in interior towns was negatively associated with the availability of hazardous products ( $\mathrm{PR}=0.68 ; 95 \% \mathrm{CI} 0.61-0.76)$, unsafe storage $(\mathrm{PR}=0.68 ; 95 \% \mathrm{CI} 0.58-0.80)$, and artisanal products $(\mathrm{PR}=0.56$; 95\%CI 0.43-0.72) when compared to living in the capital, Manaus. Households with 3-5 dwellers had more hazardous products $(\mathrm{PR}=1.24$; 95\%CI 1.14-1.35), unsafe

Table 2 Unadjusted and adjusted prevalence ratios and 95\% confidence interval of the presence of hazardous products and unsafe storage in the household $(n=4,001)$.

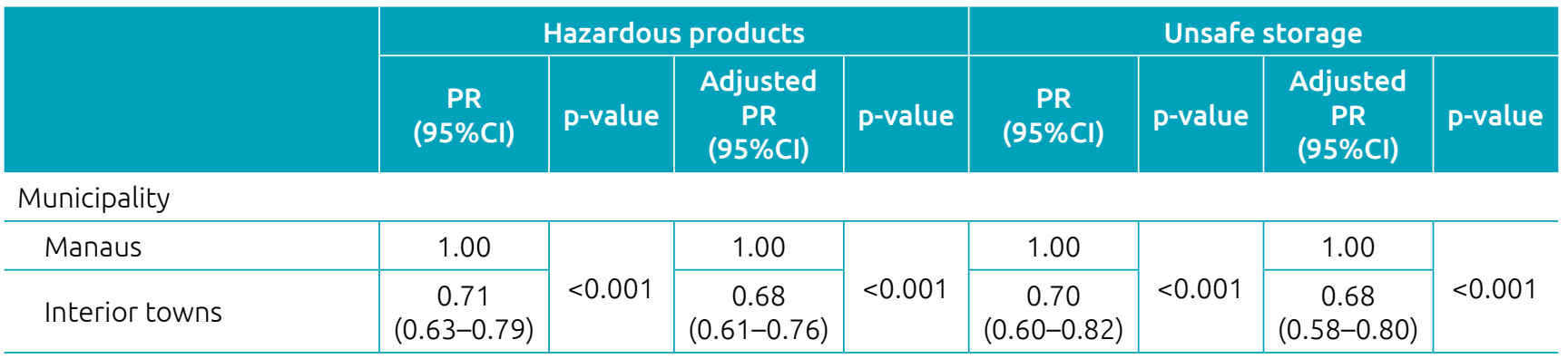

Number of dwellers

\begin{tabular}{|c|c|c|c|c|c|c|c|c|}
\hline $1-2$ & 1.00 & \multirow{3}{*}{$<0.001$} & 1.00 & \multirow{3}{*}{$<0.001$} & 1.00 & \multirow{3}{*}{$<0.001$} & 1.00 & \multirow{3}{*}{$<0.001$} \\
\hline $3-5$ & $\begin{array}{c}1.24 \\
(1.14-1.35)\end{array}$ & & $\begin{array}{c}1.24 \\
(1.14-1.35)\end{array}$ & & $\begin{array}{c}1.13 \\
(1.01-1.26)\end{array}$ & & $\begin{array}{c}1.16 \\
(1.04-1.30)\end{array}$ & \\
\hline$\geq 6$ & $\begin{array}{c}1.11 \\
(1.01-1.23)\end{array}$ & & $\begin{array}{c}1.10 \\
(0.99-1.20)\end{array}$ & & $\begin{array}{c}0.87 \\
(0.76-1.00)\end{array}$ & & $\begin{array}{c}0.96 \\
(0.82-1.11)\end{array}$ & \\
\hline
\end{tabular}

Children $\leq 5$ years old

\begin{tabular}{|c|c|c|c|c|c|c|c|c|}
\hline No & 1.00 & & 1.00 & & 1.00 & & 1.00 & \\
\hline Yes & $\begin{array}{c}0.97 \\
(0.91-1.03)\end{array}$ & 0.315 & $\begin{array}{c}0.94 \\
(0.88-1.00)\end{array}$ & 0.059 & $\begin{array}{c}0.78 \\
(0.71-0.86)\end{array}$ & $<0.001$ & $\begin{array}{c}0.78 \\
(0.71-0.86)\end{array}$ & $<0.001$ \\
\hline
\end{tabular}

\begin{tabular}{|c|c|c|c|c|c|c|c|c|}
\hline \multicolumn{9}{|l|}{ Educational level } \\
\hline Higher education or above & 1.00 & \multirow{4}{*}{$<0.001$} & 1.00 & \multirow{4}{*}{$<0.001$} & 1.00 & \multirow{4}{*}{0.044} & 1.00 & \multirow{4}{*}{0.831} \\
\hline High school & $\begin{array}{c}0.99 \\
(0.85-1.16)\end{array}$ & & $\begin{array}{c}1.01 \\
(0.86-1.18)\end{array}$ & & $\begin{array}{c}0.97 \\
(0.79-1.20)\end{array}$ & & $\begin{array}{c}1.03 \\
(0.84-1.27)\end{array}$ & \\
\hline Elementary school & $\begin{array}{c}0.96 \\
(0.82-1.12)\end{array}$ & & $\begin{array}{c}1.00 \\
(0.85-1.19)\end{array}$ & & $\begin{array}{c}0.91 \\
(0.74-1.13)\end{array}$ & & $\begin{array}{c}1.05 \\
(0.84-1.31)\end{array}$ & \\
\hline $\begin{array}{l}\text { Less than } \\
\text { elementary school }\end{array}$ & $\begin{array}{c}1.13 \\
(0.96-1.33)\end{array}$ & & $\begin{array}{c}1.22 \\
(1.03-1.44)\end{array}$ & & $\begin{array}{c}0.82 \\
(0.66-1.03)\end{array}$ & & $\begin{array}{c}0.99 \\
(0.78-1.26)\end{array}$ & \\
\hline
\end{tabular}

Economic classification

\begin{tabular}{|c|c|c|c|c|c|c|c|c|}
\hline $\mathrm{A} / \mathrm{B}$ & 1.00 & \multirow{3}{*}{0.219} & 1.00 & \multirow{3}{*}{0.233} & 1.00 & \multirow{3}{*}{$<0.001$} & 1.00 & \multirow{3}{*}{$<0.001$} \\
\hline C & $\begin{array}{c}0.93 \\
(0.86-1.01)\end{array}$ & & $\begin{array}{c}0.94 \\
(0.87-1.02)\end{array}$ & & $\begin{array}{c}0.86 \\
(0.77-0.96)\end{array}$ & & $\begin{array}{c}0.87 \\
(0.78-0.97)\end{array}$ & \\
\hline $\mathrm{D} / \mathrm{E}$ & $\begin{array}{c}0.93 \\
(0.85-1.02)\end{array}$ & & $\begin{array}{c}0.92 \\
(0.83-1.02)\end{array}$ & & $\begin{array}{c}0.71 \\
(0.62-0.81)\end{array}$ & & $\begin{array}{c}0.75 \\
(0.65-0.86)\end{array}$ & \\
\hline
\end{tabular}

Visit by Family Health Program agents*

\begin{tabular}{|c|c|c|c|c|c|c|c|c|}
\hline Yes & 1.00 & & 1.00 & & 1.00 & & 1.00 & \\
\hline No & $\begin{array}{c}0.89 \\
(0.84-0.95)\end{array}$ & $<0.001$ & $\begin{array}{c}0.86 \\
(0.81-0.92)\end{array}$ & $<0.001$ & $\begin{array}{c}0.91 \\
(0.83-0.99)\end{array}$ & 0.035 & $\begin{array}{c}0.89 \\
(0.81-0.97)\end{array}$ & $<0.001$ \\
\hline
\end{tabular}

PR: prevalence ratios; 95\% Cl: 95\% confidence interval; *in the previous 12 months. 
storage ( $\mathrm{PR}=1.16$; 95\%CI 1.04-1.30), artisanal products $(\mathrm{PR}=1.37 ; 95 \% \mathrm{CI} 1.11-1.69)$, and chumbinho $(\mathrm{PR}=1.76$; $95 \%$ CI 1.27-2.45). Households with children $\leq 5$ years old presented significantly more artisanal products $(\mathrm{PR}=1.30$; 95\% CI 1.11-1.51) but safer storage ( $\mathrm{PR}=0.78 ; 95 \% \mathrm{CI}$ $0.71-0.86)$. Having a lower educational level (less than elementary school) was positively associated with the presence of hazardous ( $\mathrm{PR}=1.22 ; 95 \% \mathrm{CI} 1.03-1.44)$ and artisanal products ( $\mathrm{PR}=2.20 ; 95 \% \mathrm{CI} 1.36-3.57)$, whereas having a lower economic classification $(\mathrm{D} / \mathrm{E})$ was negatively associated with unsafe storage $(\mathrm{PR}=0.75$; 95\%CI $0.65-0.86)$ and the presence of chumbinho ( $\mathrm{PR}=0.54 ; 95 \% \mathrm{CI} 0.38-0.77)$, and positively associated with the presence of artisanal products $(\mathrm{PR}=1.63 ; 95 \% \mathrm{CI} 1.25-2.13)$. Households not visited by the

Table 3 Unadjusted and adjusted prevalence ratios and 95\% confidence interval of the presence of artisanal products and chumbinho in the household $(n=4,001)$.

\begin{tabular}{|c|c|c|c|c|c|c|c|c|}
\hline & \multicolumn{4}{|c|}{ Artisanal products } & \multicolumn{4}{|c|}{ Chumbinho } \\
\hline & $\begin{array}{c}\text { PR } \\
(95 \% \mathrm{Cl})\end{array}$ & p-value & $\begin{array}{c}\text { Adjusted } \\
\text { PR } \\
(95 \% \mathrm{Cl})\end{array}$ & p-value & $\begin{array}{c}\text { PR } \\
(95 \% \mathrm{Cl})\end{array}$ & p-value & $\begin{array}{c}\text { Adjusted } \\
\text { PR } \\
(95 \% \mathrm{Cl})\end{array}$ & p-value \\
\hline \multicolumn{9}{|l|}{ Municipality } \\
\hline Manaus & 1.00 & \multirow{2}{*}{$<0.001$} & 1.00 & \multirow[b]{2}{*}{$<0.001$} & 1.00 & \multirow[b]{2}{*}{0.133} & 1.00 & \multirow[b]{2}{*}{0.221} \\
\hline Interior towns & $\begin{array}{c}0.62 \\
(0.48-0.80)\end{array}$ & & $\begin{array}{c}0.56 \\
(0.43-0.72)\end{array}$ & & $\begin{array}{c}0.77 \\
(0.54-1.08)\end{array}$ & & $\begin{array}{c}0.81 \\
(0.57-1.14)\end{array}$ & \\
\hline
\end{tabular}

Number of dwellers

\begin{tabular}{|c|c|c|c|c|c|c|c|c|}
\hline $1-2$ & 1.00 & \multirow{3}{*}{0.001} & 1.00 & \multirow{3}{*}{0.010} & 1.00 & \multirow{3}{*}{0.001} & 1.00 & \multirow{3}{*}{0.002} \\
\hline $3-5$ & $\begin{array}{c}1.41 \\
(1.15-1.73)\end{array}$ & & $\begin{array}{c}1.37 \\
(1.11-1.69)\end{array}$ & & $\begin{array}{c}1.79 \\
(1.31-2.45)\end{array}$ & & $\begin{array}{c}1.76 \\
(1.27-2.45)\end{array}$ & \\
\hline$\geq 6$ & $\begin{array}{c}1.50 \\
(1.19-1.89)\end{array}$ & & $\begin{array}{c}1.21 \\
(0.95-1.56)\end{array}$ & & $\begin{array}{c}1.50 \\
(1.04-2.16)\end{array}$ & & $\begin{array}{c}1.52 \\
(1.02-2.27)\end{array}$ & \\
\hline
\end{tabular}

Children $\leq 5$ years old

\begin{tabular}{|c|c|c|c|c|c|c|c|c|}
\hline No & 1.00 & & 1.00 & & 1.00 & & 1.00 & \\
\hline Yes & $\begin{array}{c}1.38 \\
(1.16-1.54)\end{array}$ & $<0.001$ & $\begin{array}{c}1.30 \\
(1.11-1.51)\end{array}$ & 0.001 & $\begin{array}{c}0.98 \\
(0.80-1.22)\end{array}$ & 0.880 & $\begin{array}{c}0.90 \\
(0.72-1.14)\end{array}$ & 0.386 \\
\hline
\end{tabular}

\begin{tabular}{|c|c|c|c|c|c|c|c|c|}
\hline \multicolumn{9}{|l|}{ Educational level } \\
\hline Higher education or above & 1.00 & \multirow{4}{*}{$<0.001$} & 1.00 & \multirow{4}{*}{$<0.001$} & 1.00 & \multirow{4}{*}{0.094} & 1.00 & \multirow{4}{*}{0.250} \\
\hline High school & $\begin{array}{c}1.18 \\
(0.74-1.88)\end{array}$ & & $\begin{array}{c}1.03 \\
(0.65-1.66)\end{array}$ & & $\begin{array}{c}1.12 \\
(0.65-1.92)\end{array}$ & & $\begin{array}{c}1.30 \\
(0.75-2.24)\end{array}$ & \\
\hline Elementary school & $\begin{array}{c}1.24 \\
(0.77-2.00)\end{array}$ & & $\begin{array}{c}0.99 \\
(0.61-1,61)\end{array}$ & & $\begin{array}{c}0.81 \\
(0.46-1.42)\end{array}$ & & $\begin{array}{c}1.05 \\
(0.59-1.87)\end{array}$ & \\
\hline $\begin{array}{l}\text { Less than } \\
\text { elementary school }\end{array}$ & $\begin{array}{c}2.78 \\
(1.75-4.43)\end{array}$ & & $\begin{array}{c}2.20 \\
(1.36-3.57)\end{array}$ & & $\begin{array}{c}0.96 \\
(0.54-1.71)\end{array}$ & & $\begin{array}{c}1.38 \\
(0.75-2.53)\end{array}$ & \\
\hline
\end{tabular}

Economic classification

\begin{tabular}{|c|c|c|c|c|c|c|c|c|}
\hline$A / B$ & 1.00 & \multirow{3}{*}{$<0.001$} & 1.00 & \multirow{3}{*}{$<0.001$} & 1.00 & \multirow{3}{*}{$<0.001$} & 1.00 & \multirow{3}{*}{0.002} \\
\hline C & $\begin{array}{c}1.33 \\
(1.04-1.70)\end{array}$ & & $\begin{array}{c}1.27 \\
(0.99-1.63)\end{array}$ & & $\begin{array}{c}0.67 \\
(0.52-0.87)\end{array}$ & & $\begin{array}{c}0.69 \\
(0.54-0.90)\end{array}$ & \\
\hline $\mathrm{D} / \mathrm{E}$ & $\begin{array}{c}2.10 \\
(1.63-2.70)\end{array}$ & & $\begin{array}{c}1.63 \\
(1.25-2.13)\end{array}$ & & $\begin{array}{c}0.51 \\
(0.37-0.70)\end{array}$ & & $\begin{array}{c}0.54 \\
(0.38-0.77)\end{array}$ & \\
\hline
\end{tabular}

Visit by Family Health Program agents*

\begin{tabular}{|c|c|c|c|c|c|c|c|c|}
\hline Yes & 1.00 & \multirow[b]{2}{*}{0.132} & 1.00 & \multirow[b]{2}{*}{0.005} & 1.00 & \multirow[b]{2}{*}{0.929} & 1.00 & \multirow[b]{2}{*}{0.860} \\
\hline No & $\begin{array}{c}0.89 \\
(0.77-1.04)\end{array}$ & & $\begin{array}{c}0.81 \\
(0.70-0.94)\end{array}$ & & $\begin{array}{c}0.99 \\
(0.79-1.24)\end{array}$ & & $\begin{array}{c}1.02 \\
(0.81-1.28)\end{array}$ & \\
\hline
\end{tabular}

PR: prevalence ratios; 95\%Cl: 95\% confidence interval; *in the previous 12 months. 
Family Health Program in the previous year had lower availability of hazardous products ( $\mathrm{PR}=0.86$; 95\% CI 0.81-0.92), unsafe storage ( $\mathrm{PR}=0.89$; 95\% CI $0.81-0.97)$, and artisanal products ( $\mathrm{PR}=0.81 ; 95 \% \mathrm{CI} 0.70-0.94)$. The deviance and Pearson Goodness-of-Fit tests for all regressions suggested that the adjusted models were appropriate $(\mathrm{p}>0.05)$.

\section{DISCUSSION}

The availability of hazardous and artisanal products, and unsafe storage were associated with living in the capital and having three or more dwellers in the same household. The presence of children $\leq 5$ years old was associated with safer product storage and higher availability of artisanal cleaning products. Lower educational levels increased the availability of hazardous and artisanal products, whereas lower economic classification was associated with higher presence of artisanal products, lower availability of chumbinho, and safer storage of products. Visits by the Family Health Program did not reduce the availability and unsafe storage of hazardous products.

Households located in interior towns had fewer hazardous and artisanal products, and reported safer storage of cleaning products and medications. A retrospective study conducted in a Polish hospital analyzed the medical records of 848 children admitted to the institution due to poisoning exposures, from 2008 to 2012, and observed that poisoning was more frequent in urban children than in those living in rural areas, ${ }^{17}$ which may be explained by a lower access to these products among countryside residents.

Higher numbers of dwellers living in the same household increased the availability of hazardous products and unsafe storage. This may be a result of a higher use and access to potentially harmful products. Childhood unintentional injuries, such as burns, are more likely to occur in crowded households, as suggested by a case-control study conducted in Rio de Janeiro, Brazil, between 1991 and $1992 .{ }^{18}$ Another epidemiological study carried out in Greece with 1,245 children, aged up to 5 years old, indicated that child poisoning is correlated with overcrowding at home, which could lead to uncontrolled settings and, consequently, to difficulties in monitoring the child's behavior. ${ }^{19}$

Households with children $\leq 5$ years old had safer storage of cleaning products and medications, indicating a better care by guardians. Most reported cases of poisonings from a study that included five hospitals in Australia occurred in an unsupervised time span of five minutes or less, and the most common means of access were during the usage of agents, accounting for three quarters of the total cases. ${ }^{20}$ From 2010 to 2013, parents of over 500 poisoned children, aged 0-4 years old, in England, were less likely to store medications out of reach or safely locked, and to put medications and household products away immediately after use. ${ }^{1}$

Younger children are the most vulnerable group for inherent reasons, because they are prone to insert objects and liquids in their mouths, have less evolved perceptions of taste, and lack awareness about the dangers involved, which can be minimized by the usage of less appealing packages and label content for children. ${ }^{21,22}$ Children also have a lower body weight. Therefore, the amount of substance required to reach concentrations that can cause damage is significantly lower.

Effective measures to prevent child poisoning exposure inside their households include poison prevention education to parents, provision of emergency contact numbers of poison control centers, and safe storage of hazardous products in cupboard/drawer locks. ${ }^{23,24}$ When safe storage fails, other tactics may help prevent poisoning, such as improved labelling and/or packaging, and the use of safe bottles, which consist of a lid that is hard to open, requiring more strength than children usually have..$^{20,25,26}$

Participants with lower educational levels were associated with a higher availability of hazardous and artisanal products. Lower economic classification was positively associated with the presence of artisanal products, but negatively associated with availability of chumbinho and unsafe storage. A Danish analysis of 173,504 children treated in emergency departments, from 1998 to 2003, observed a higher risk of unintentional home injuries in children whose mothers had lower education attainment and in those from the lowest income stratum. ${ }^{27}$ Plausible explanations for these differences are the awareness of dangerous practices and the development of safety habits among those with higher educational levels, and the possibility of living in safer households with reduced exposure risks among high-income families, who can afford safer equipment. ${ }^{27}$ Artisanal cleaning products were also more frequent in these households, which can result in higher toxicity in comparison to regulated products. ${ }^{12} \mathrm{~A}$ cross-sectional study that collected data from a Brazilian Poison Control Center, between 2013 and 2014, found that toxic clinical manifestations were significantly more frequent after illegal products exposure, often leading to hospitalizations and surgeries. ${ }^{12}$

Visits by the Family Health Program did not reduce the availability and unsafe storage of hazardous products; instead, lower presence of hazardous products, unsafe storage, and artisanal products were observed in households not visited in the previous year. In most Brazilian settings, communitarian health 
agents who visit households have several assignments, and are frequently underpaid, overworked, and unrecognized..$^{28}$ This may have an impact on the level of information and assistance provided by these professionals. A qualitative study conducted in 2016 with 50 healthcare professionals from the Family Health Program showed that educational practices related to childhood poisoning promoted by these agents were mainly focused on first aids concepts, with little discussion on actual poisoning accident prevention strategies. ${ }^{29}$ If adopted by the Family Health Program agents, directed poisoning prevention education to parents - including increasing knowledge of poisons and poisoning prevention behaviors such as safe storage of medications and cleaning products - could possibly reduce childhood poisoning rates. ${ }^{24}$ Prevention with education improves poisoning prevention practices and encourages the need of legislative measures, such as those related to childproof bottles. ${ }^{24}$ The potential of the Family Health Program, however, may be compromised in the near future, because changes in the Brazilian Primary Healthcare Policy allowed a reduction in the size and components of Family Health Program teams. ${ }^{30}$

Interviews were held with one individual from each household, without objective confirmation of responses, which limits the validity of results. As the options of products available at home were repetitive, desensitization of respondents may have occurred. Such caveats may impact the assessment and represent information bias in the study. Considering the survey investigated many outcomes in only one interview, the study did not include poison prevention measures or follow-up with participants. We did not assess the incidence of poisoning of investigated products and, consequently, we cannot provide implications of the availability of hazardous products. Sample size calculations were based on estimates of health services usage, and the assessment of the outcomes of the present analysis was not planned.

In conclusion, over half households from the metropolitan region of Manaus kept hazardous products, and these products were stored unsafely in one-third of the domiciles. Artisanal cleaning products and chumbinho were frequently available in households. Unfavorable socioeconomic factors increased the availability of hazardous products.

\section{Funding}

The present paper was supported by the Brazilian National Council for Scientific and Technological Development (Conselho Nacional de Desenvolvimento Cientifico e Tecnológico - CNPq) under Grants No. 404990/2013-4 and 448093/2014-6.

\section{Conflict of interests}

The authors declare there is no conflict of interests.

\section{REFERENCES}

1. Kendrick D, Majsak-Newman G, Benford P, Coupland C, Timblin $C$, Hayes $M$, et al. Poison prevention practices and medically attended poisoning in young children: multicentre case-control study. Inj Prev. 2017;23:93-101. https://doi. org/10.1136/injuryprev-2015-041828

2. Kyu HH, Stein CE, Pinto CB, Rakovac I, Weber MW, Purnat TD, et al. Causes of death among children aged 5-14 years in the WHO European Region: a systematic analysis for the Global Burden of Disease Study 2016. Lancet Child Adolesc Health. 2018;2:321-37. https://doi.org/10.1016/ s2352-4642(18)30095-6

3. Kassebaum N, Kyu HH, Zoeckler L, Olsen HE, Thomas K, Pinho C, et al. Child and adolescent health from 1990 to 2015: findings from the Global Burden of Diseases, Injuries, and Risk Factors 2015 Study. JAMA Pediatr. 2017;171:573-92. https://doi.org/10.1001/jamapediatrics.2017.0250

4. GBD 2016 Disease and Injury Incidence and Prevalence Collaborators. Global, regional, and national incidence, prevalence, and years lived with disability for 328 diseases and injuries for 195 countries, 1990-2016: a systematic analysis for the Global Burden of Disease Study 2016. Lancet. 2017;390:1211-59. https://doi.org/10.1016/S0140-6736(17)32154-2
5. Gummin DD, Mowry JB, Spyker DA, Brooks DE, Beuhler MC, Rivers LJ, et al. 2018 Annual Report of the American Association of Poison Control Centers' National Poison Data System (NPDS): 36th Annual Report. Clin Toxicol (Phila). 2019;57:1220-413. https://doi.org/10.1080/15563650.2019.1677022

6. Faruque $A V$, Khan MA. Unintentional injuries in children: are our homes safe? J Coll Physicians Surg Pak. 2016;26:445-6.

7. Huynh A, Cairns R, Brown JA, Lynch AM, Robinson J, Wylie C, et al. Patterns of poisoning exposure at different ages: the 2015 annual report of the Australian Poisons Information Centres. Med J Aust. 2018;209:74-9. https://doi.org/10.5694/ mja17.01063

8. Nistor N, Frasinariu OE, Rugina A, Ciomaga IM, Jitareanu C, Streanga V. Epidemiological study on accidental poisonings in children from northeast romania. Medicine (Baltimore). 2018;97:e11469. https://doi.org/10.1097/ MD.0000000000011469

9. Tangiisuran B, Jiva M, Ariff AM, Rani NA, Misnan A, Rashid $\mathrm{SM}$, et al. Evaluation of types of poisoning exposure calls managed by the Malaysia National Poison Centre (20062015): a retrospective review. BMJ Open. 2018;8:e024162. https://doi.org/10.1136/bmjopen-2018-024162 
10. Vilaça L, Volpe FM, Ladeira RM. Accidental poisoning in children and adolescents admitted to a referral toxicology department of a BrazilianEmergency hospital. Rev Paul Pediatr. 2020;38:e2018096. https://doi.org/10.1590/1984-0462/2020/38/2018096

11. World Health Organization. World report on child injury prevention. Geneva: WHO; 2008.

12. Campos AM, Bucaretchi F, Fernandes LC, Fernandes CB, Capitani EM, Beck AR. Toxic exposures in children involving legally and illegally commercialized household sanitizers. Rev Paul Pediatr. 2017;35:11-7. http://dx.doi.org/10.1590/19840462/;2017;35;1;00010

13. Silva MT, Galvao TF. Use of health services among adults living in Manaus Metropolitan Region, Brazil: populationbased survey, 2015. Epidemiol Serv Saude. 2017;26:725-34. http://dx.doi.org/10.5123/s1679-49742017000400005

14. Associação Brasileira de Empresas de Pesquisa. Critério de Classificação Econômica Brasil 2015. São Paulo: ABEP; 2015.

15. Warner SL. Randomized response: a survey technique for eliminating evasive answer bias. J Am StatAssoc. 1965;60:63-9. https://doi.org/10.1080/01621459.1965.10480775

16. Long JS, Freese J. Regression Models for categorical dependent variables using stata. $3^{\text {rd }}$ ed. College Station, TX: Stata Press; 2014.

17. Pac-Kożuchowska E, Krawiec P, Mroczkowska-Juchkiewicz A, Metges B, Pawtowska-Kamieniak A, Kominek K, et al. Patterns of poisoning in urban and rural children: a singlecenter study. Adv Clin Exp Med. 2016;25:335-40. https:// doi.org/10.17219/acem/36142

18. Werneck GL, Reichenheim ME. Paediatric burns and associated risk factors in Rio de Janeiro, Brazil. Burns. 1997;23:478-83. https://doi.org/10.1016/s0305-4179(97)00046-6

19. Paritsis N, Pallis D, Deligeorgis D, Doxiadis S, Phylactou C, Vlachonicolis I. An epidemiological study of the factors influencing poisoning in children aged 0-5 years. Paediatr Perinat Epidemiol. 1994;8:79-89. https://doi. org/10.1111/j.1365-3016.1994.tb00437.x

20. Ozanne-Smith J, Day L, Parsons B, Tibballs J, Dobbin M. Childhood poisoning: access and prevention. J Paediatr Child Health. 2001;37:262-5. https://doi.org/10.1046/j.1440-1754.2001.00654.x
21. White ND, Kibalama W. Prevention of pediatric pharmaceutical poisonings. Am J Lifestyle Med. 2017;12:117-9. https://doi. org/10.1177/1559827617745014

22. Mennella JA, Beauchamp GK. Optimizing oral medications for children. Clin Ther. 2008;30:2120-32. https://doi. org/10.1016/j.clinthera.2008.11.018

23. O'Donnell KA. Pediatric toxicology: household product ingestions. Pediatr Ann. 2017;46:e449-53. https://doi. org/10.3928/19382359-20171120-04

24. Wynn PM, Zou K, Young B, Majsak-Newman G, Hawkins A, Kay $B$, et al. Prevention of childhood poisoning in the home: overview of systematic reviews and a systematic review of primary studies. Int J Inj Contr Saf Promot. 2016;23:3-28. https://doi.org/10.1080/17457300.2015.1032978

25. Talukder BB, Jovanov E, Schwebel DC, Evans WD. A new method to prevent unintentional child poisoning. Conf Proc IEEE Eng Med Biol Soc. 2018;2018:5142-5. https:// doi.org/10.1109/embc.2018.8513459

26. Schwebel DC, Evans WD, Hoeffler SE, Marlenga BL, Nguyen SP, Jovanov E, et al. Unintentional child poisoning risk: a review of causal factors and prevention studies. Child Health Care. 2017;46:109-30. https://doi.org/10.1080/02739615. 2015.1124775

27. Laursen B, Nielsen JW. Influence of sociodemographic factors on the risk of unintentional childhood home injuries. Eur J Public Health. 2008;18:366-70. https://doi.org/10.1093/ eurpub/ckn034

28. Guanaes-Lorenzi C, Pinheiro RL. Is the value of Community Healthcare Agents in Brazil's family health strategy receiving full recognition? Cienc Saude Colet. 2016;21:2537-46. https:// doi.org/10.1590/1413-81232015218.19572015

29. Sales CC, Oliveira ML. Health education practices of poisoning prevention for child in Family Health Strategy. Esc Anna Nery. 2019;23:e20180140. https://doi.org/10.1590/21779465-ean-2018-0140

30. Morosini MV, Fonseca AF. Reviewing the Brazilian National Primary Healthcare Policy at such a time? Cad Saude Publica. 2017;33:e00206316. https://doi.org/10.1590/0102$311 \times 00206316$ 